\title{
On Cultivating Innovative Entrepreneurship Education of Local Agricultural University Students
}

\author{
Hua Li ${ }^{1, a}$, Lina Zhou ${ }^{2, b}$ and Yueming Yuan ${ }^{3, c^{*}}$ \\ ${ }^{1,2,3}$ College of engineering and technology, Jilin Agricultural University \\ Xincheng Street 2888, Jilin Agricultural University, Changchun, Jilin Province 130118, PR China \\ a1544543@163.com, ‘yym_jlu@163.com \\ * The Corresponding author
}

Keywords: Local Agricultural Colleges; Innovation and Entrepreneurship Education; Training Approach

\begin{abstract}
This paper analyzes the connotation and characteristics of college students' innovation and entrepreneurship education, and puts forward that the training methods of innovation and entrepreneurship education of local agricultural colleges and universities mainly include the following aspects: strengthening ideological and political education, reforming and innovating entrepreneurship education curriculum system, Establish the innovation and education system, strengthen the students to participate in scientific and technological innovation activities, broaden the platform for innovation and entrepreneurship practice.

The Fifth Plenary Session of the Eighteenth National Congress put forward that the state should adhere to innovation and development, lay the core position of innovation in the overall development of the country, and demand the promotion of public entrepreneurship and innovation to promote the rapid development of the national economy. At the meeting, it is proposed to promote the coordinated development of urban and rural areas, hoping to improve the level of building a new socialist countryside by improving the rural infrastructure and promoting the extension of urban official services to rural areas. As an important base for cultivating agricultural modernization talents and developing rural science and technology, local agricultural colleges and universities should vigorously promote innovation and entrepreneurship education for college students.
\end{abstract}

\section{The Connotation and Characteristics of Innovation and Entrepreneurship Education}

Innovation is a conceptual process of integrating new ideas, new inventions and new descriptions. The cultivation of innovative thinking depends on a strong interest, a wealth of knowledge reserves and explore the attitude of seeking different. Entrepreneurial quality is an important part of personal qualities, including the ideological and moral quality, professional and scientific and cultural quality, physical and psychological quality ${ }^{[1]}$. The entrepreneurial quality of college students is an indispensable part of quality education in colleges and universities. The entrepreneurial ability of college students also needs social ability, cognitive ability and practical operation ability. Therefore, the comprehensive, innovative entrepreneurship education is aim to cultivate innovative quality and personality to create a personality as the goal of a disease practical education. Mainly including innovation and entrepreneurship awareness, spirit and ability and other aspects of the content.

Innovation and entrepreneurship education is a kind of systematic educational activities, including the cultivation of students 'creative and entrepreneurial awareness, the improvement of students' entrepreneurial entrepreneurial ability, the accurate cognition of innovation and entrepreneurial environment, and the study of innovative business practice. Innovative entrepreneurship education is innovative, creative, practical and practical and so on. 


\section{The Training Approach of Students Innovative Entrepreneurship in the Local Agricultural Colleges and Universities}

Strengthen the Ideological and Current Affairs of Political Education. Ideological and political education of college students is the central link of school education. First, it is necessary to incorporate current political education and school education into freshmen education. Through the guidance of new students to learn about innovation and entrepreneurship education support policies to help students build a sense of innovation and entrepreneurship. Local agricultural institutions organize students to visit the school history museum, to understand the history of the school, to understand the development of agricultural science and technology, so as to stimulate students to serve the passion of agriculture ${ }^{[2]}$.Second, the school should actively carry out lectures and seminars and other after-school activities, by inviting the school innovation and entrepreneurship achievements of the students came to the school to share their innovative business process, to encourage students to actively carry out entrepreneurship business.

Reform and Innovation of Entrepreneurship Education Curriculum System. Local agricultural institutions should actively respond to national policies, will be innovative entrepreneurship education into college students training system. Open innovation and entrepreneurship students public courses, cultivating college students' awareness of innovation and entrepreneurship, innovation and entrepreneurship to help them understand the policy and market environment, adhere to the professional teaching, the principle of combining theory and practice, improve students' innovative ability and quality. You can choose to open in the second and third grade, such as KAB simulation business courses, while opening similar to China Agricultural Science and Technology Innovation Entrepreneurship Competition and other entrepreneurial competition projects, which can enrich the entrepreneurial knowledge system.

Institutions Improve the Innovation of Education and Education Mechanism. In order to provide a better environment for innovation and entrepreneurship education, local agricultural colleges and universities should, according to the characteristics of local agriculture development and the environmental characteristics of innovation and entrepreneurship, improve the guarantee mechanism of innovation and entrepreneurship education, establish a sound teaching, employment, research, counselor groups As well as college students innovation and entrepreneurship and other departments to coordinate the development mechanism ${ }^{[3]}$. The establishment of incentives, through the identification of credits and other material and ideological incentives to encourage students to participate in various forms of innovative business activities. At the same time, for the innovation and entrepreneurship performance of the student schools to carry out financial and technical guidance and other aspects of support. Innovation and entrepreneurship education will form a concept, a long-term mechanism, through the local government, institutions and social families to form education together, focusing on ensuring the smooth development of innovative entrepreneurship education.

Improve the Innovation and Entrepreneurship Education Evaluation System. The evaluation system of innovation and entrepreneurship education is the value judgment of innovation and entrepreneurship teaching objectives, tasks and teaching effect, teaching quality and students' learning situation. According to the evaluation results, it is timely to carry out the reform of the innovation and entrepreneurship education mechanism. The evaluation system of innovation and entrepreneurship of local agricultural colleges should be evaluated according to local economic level, local government support, school orientation and professional characteristics.

To Cultivate Innovative Entrepreneurship Education Teachers. At present, the enthusiasm of college students innovation and entrepreneurship, schools and society will provide some innovative business projects to students to practice learning. However, the lack of professional guidance to innovate entrepreneurship education faculty. To this end, the school can invite the school to start a more successful graduates as a school innovation and entrepreneurship education part-time instructor, in the community to hire relevant professional teachers or by the school innovation and entrepreneurship project rich teachers to form full-time instructor. At the same time, to encourage graduate students and undergraduates to form an innovative business project team, 
please get excellent achievements of the entrepreneurial team members of the students to give guidance on innovation and entrepreneurship. This part-time + full-time + excellent team members of the model constitutes a creative entrepreneurial education professional teachers ${ }^{[4]}$.In addition, the innovative team of students should be equipped with at least a teacher and an experienced graduate, this allows students to encounter problems in the innovation period can timely consult resolved effectively, promote the students' innovation and entrepreneurship in the road to success in a great extent.

Finally, to give guidance to teachers to participate in the work of innovation and entrepreneurship education activities recognized, for the guidance of innovative entrepreneurship team to achieve excellent results, the school should give the teacher corresponding bonus, title and other reward system, the teacher's title assessment and innovation and entrepreneurship Education, the actual performance of the link, a great promotion of teachers to participate in student innovation and entrepreneurship education enthusiasm, but also to encourage teachers to constantly improve their professional quality, and thus more professional guidance students innovative business activities.

To actively encourage students to participate in innovation and entrepreneurship science and technology activities

To Actively Encourage Students to Participate in Innovation and Entrepreneurship Science and Technology Activities. In order to actively cultivate students' innovative spirit and improve the ability of innovation and entrepreneurship of college students, the school should actively encourage students to participate in innovation and entrepreneurship and science and technology activities, including the following: First, set up to include students to participate in scientific and technological innovation activities of personnel training programs, science and technology innovation activities will be clearly divided into specific credit system. Encourage students to participate in entrepreneurial design competition, participate in the national college students innovative experimental program and college students "Challenge Cup" Entrepreneurship Program Competition and other innovative business activities to broaden the students 'innovative business vision, cultivate students' scientific spirit and innovative entrepreneurial awareness and create a strong The atmosphere of innovation and entrepreneurship, training students innovative entrepreneurial quality. Second, the combination of innovative entrepreneurship education and agricultural science and technology projects. The combination of innovative entrepreneurship education and agricultural scientific research projects and agricultural science and technology centers in the local agricultural colleges and universities to encourage students to actively respond to the call of the Party Central Committee, to the grassroots to carry out business employment, to encourage students to rural areas to understand the development of agricultural science and technology The status quo, to carry out practical research projects, and constantly reform the agricultural science and technology, the theoretical knowledge given to practice, improve the level of science and technology of college students, enrich the practical quality of college students, so as to promote the development of innovation and entrepreneurship ${ }^{[5]}$.

To Broaden the Practice of Innovation and Entrepreneurship Education Platform. First of all, in the campus set up within the college students innovation and entrepreneurship training park. The training center is headed by a professional innovation and entrepreneurship teacher. At the same time, the training teacher can also join the instructor who is familiar with the basic situation of the student and the teacher of the grade class. This is convenient for the students to carry out the education and training of innovative entrepreneurship education. In addition, the training center in addition to innovation and entrepreneurship students to give technical guidance, but also should provide the necessary school policies, funds and resources to help students in the early stages of innovation and entrepreneurship through the difficulties, foster students innovative business projects continue to develop. Second, the local agricultural institutions should also be combined with the field of agricultural research base. As a student practice and employment practice base, to strengthen the link with the local agricultural enterprises to help students build innovative business 
practice platform for students to innovate and create the necessary practical experience, so as to stimulate students' enthusiasm for innovation and entrepreneurship.

In this paper, from the strengthening of ideological and current affairs of political education, reform and innovation of entrepreneurship education curriculum system, institutions improve the innovation of education and education mechanism, improve the innovation of entrepreneurship education evaluation system, cultivate innovative entrepreneurship education teachers, and actively encourage students to participate in innovative entrepreneurial science and technology activities and To explore the practice of innovation and entrepreneurship platform seven major aspects of the local agricultural colleges and universities to explore innovative ways of training entrepreneurship education. Hoping to give some local agricultural colleges and universities in different provinces of innovation and entrepreneurship education to provide some ways to learn and help.

\section{References}

[1] Liu Yuexiu, Liu Hui. The way to cultivate the entrepreneurial quality of College Students under the background of new rural construction [J]. Guangdong Agricultural Sciences, 2012, (06): 170-172.

[2] Liu Qiang, Liu Haoyuan. Study on the Ways of Cultivating Undergraduate Talents of Agricultural Entrepreneurship - Taking Hunan Agricultural University as an Example [J]. Chinese Journal of Higher Education Research, 2008, (08): 61-62.

[3] Lu Kaiyan. Undergraduate college liberal arts students innovation and entrepreneurship ability training countermeasures [J]. Liaoning economy, 2014, (10): 80-81.

[4] Cui Xiaoling. Thinking on the construction of College Students' entrepreneurial quality in Local Normal Colleges and universities and its training methods [J]. Journal of Jiamusi Education Institute, 2014, (04): 137+141.

[5] Wu Yantao, Han Tongji, He Jing. Agricultural Universities of "three steps" innovation and entrepreneurship education model [J].Social Science Journal of Shenyang Agricultural University(SOCIAL SCIENCE EDITION), 2012, (06): 698-700. 